\title{
Negative word-order patterns among Breton-speaking adults and children
}

Holly Winterton, University of Oxford

\section{BACKGROUND}

Breton has been in decline throughout the twentieth century, particularly following the end of the Second World War. Today, there are two main groups of speakers: older speakers, who learnt Breton at home from their parents, before learning French; and younger speakers, who learnt or are learning Breton through schooling, and whose parents usually speak only French. A gap has arisen in the transmission of Breton between these two generations. The standardised Breton of schools has also been identified as being different from that of older speakers (Hornsby, 2005). This so-called Neo Breton avoids French loanwords in favour of more 'Celtic' equivalents, but also differs in terms of its sentence structure, which tends to be influenced by that of French.

Breton word order has been the subject of much debate since Varin's (1979) article, in which she argues that Modern Breton matrix clauses have SVO word order, in contrast to earlier studies, which considered Breton to be typologically verb-initial (Kervella, 1947). Varin attributes this to language change, and other writers following her line of argument remark that this could be due to influence from French (e.g. Heine and Kuteva, 2005). Other writers, however, (such as Timm, 1989) maintain that the word order of Breton remains VSO, in line with other Celtic languages.

This presents an interesting angle for the study of the transmission gap in Modern Breton: what effect is it having on word order? This paper aims to uncover how both older and also younger speakers are using word order in Breton. The focus is on negative progressive utterances; there is some consensus as to the established word order in negative clauses (e.g. Press, 1986; Ternes, 1992), and focusing on negative utterances avoids the somewhat problematic nature of Breton non-negative clauses, where two alternative constructions are possible. The discussion begins with a brief introduction to Breton syntax, before examining fieldwork data, and considering its implications.

\section{BRETON}

Like other Celtic languages, Breton has preverbal particles. It is verb-second (V2) in matrix clauses, and the preverbal 'slot' can be filled by a number of different constituents. The preverbal negative particle $n e$ is also able to satisfy the V2 constraint; other preverbal particles cannot. $\mathrm{Ne}$ can also be preceded by the subject without violating the V2 constraint. Breton is a pro-drop language, and pronominal subjects need not necessarily be overtly expressed. Negative utterances are formed with two negative particles, ne and ket, which are analogous to the French ne...pas. Ne is often omitted in fast speech.

1. ne gomz -an ket galleg

NEG speak -1SG NEG French

'I do not speak French.'

Progressive utterances are formed with an auxiliary (the situational form of bezañ 'to be', normally used to express a location) and the verbal noun, preceded by the particle $o$ (or $o c^{\prime} h$ before a vowel). $O\left(c^{\prime} h\right)$, like $n e$, can be omitted in fast speech.

2. emaon o tigeriñ an nor be.SIT.1SG PRT open.PROG DET door 'I am opening the door.' 
The expected word order for negative progressive utterances in Breton, as set out in Press (1986) and Ternes (1992) (among others), is as follows:

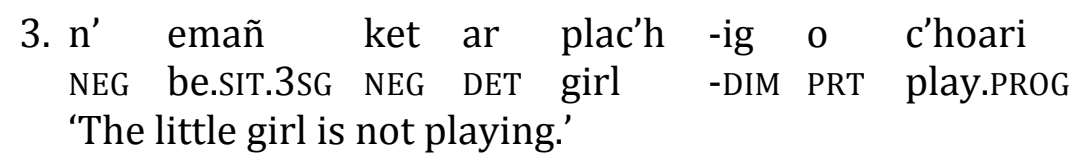

However, an alternative order, which is equally valid, places the subject in initial position:

4. ar plac'h -ig n' emañ ket o c'hoari

DET girl -DIM NEG be.SIT.3SG NEG PRT play.PROG

'The little girl is not playing.'

This is generally considered to result in emphasis on the subject, but Varin maintains that Breton is shifting towards this as the unmarked word order.

\section{DISCUSSION}

\subsection{FIELDWORK METHOdOLOGY}

Three groups of speakers from the area surrounding Quimper (Finistère) were interviewed for the fieldwork: first, senior adults, who are older speakers aged at least 70; secondly, children currently in Breton-medium education; and thirdly, young adults, who have formerly received some Breton education. Photographs and short films (5-10 seconds) were used to elicit utterances. Speakers were asked, 'what's happening?', to elicit a context-free utterance. Breton word order is partly pragmatically determined: a question such as 'What colour is the paper?' would elicit the response 'Blue is the paper'; whereas the question 'What is blue?' would elicit 'The paper is blue'. Such pragmatically marked utterances were therefore avoided, for fear that the word order used would not be a true representation of neutral word order. To elicit negative utterances, participants were shown pictures with a large red X over the top.

\subsection{SENIOR ADULTS}

All of the senior adults grew up speaking Breton at home, and several spoke no French before going to school (aged six). Eight speakers were interviewed, and three produced sufficient data for negative utterances. The utterances were then 'classified' as subject-initial, finite verb initial (following the negative particle) or 'other'. For example:

5. Participant G

a. (NEG) + Finite Verb-initial

(n') emaint ket (o) c'hoarzin

(NEG) be.SIT.3PL NEG (PRT) laugh.PROG

'They are not laughing.'

\section{b. Subject-initial}

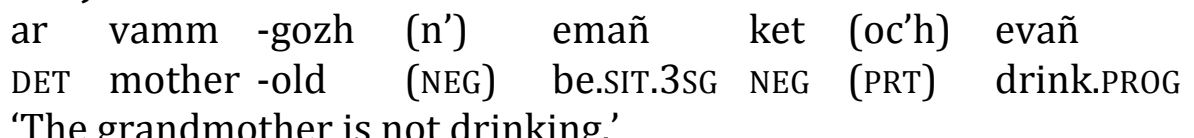

The senior adults were very consistent in usage, and overall 88 per cent of their utterances were finite verb-initial (as in 5a), with only ten per cent of utterances subject-initial. 


\subsection{CHILDREN}

Ten children, aged 8-13, were interviewed in this study and attend two types of school: the Diwan private immersion school, or the Divyezh bilingual stream, which is state-run and operates in a 'normal' state school. In Diwan schools children are taught exclusively in Breton; French comes later. In contrast, in the bilingual stream, children are taught to read and write in French while other lessons are conducted in Breton. It seems that the type of schooling the children receive is crucial in terms of their use of word order.

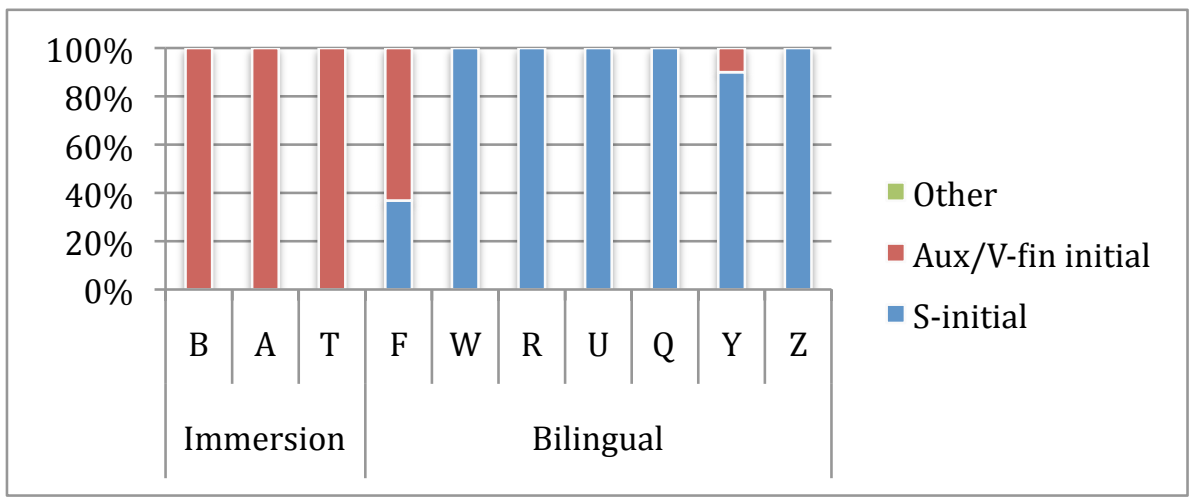

\section{FIGURE 1: CHILDREN'S DATA}

The immersion children follow the senior adults' (NEG) + finite verb pattern, while the bilingual children use subject-initial order, as in French. However, this is not the whole story: $\mathrm{F}$ is at a bilingual school, yet uses predominantly finite verb-initial word order. It is at this point that input from home seems to be important. All the children come from French-speaking homes, but $\mathrm{F}$ also speaks Breton with her grandmother: an older, traditional speaker. The other children do not have any such input from family members. $F$ therefore differs from her peers and is halfway between the two groups.

\subsection{Young Adults}

There is quite a gap between children or young teenagers and adults in terms of development, and so data were collected from seven younger adults, aged 20-30, all of whom had undergone some schooling or classes in Breton, and who now use Breton on a daily basis through their work.

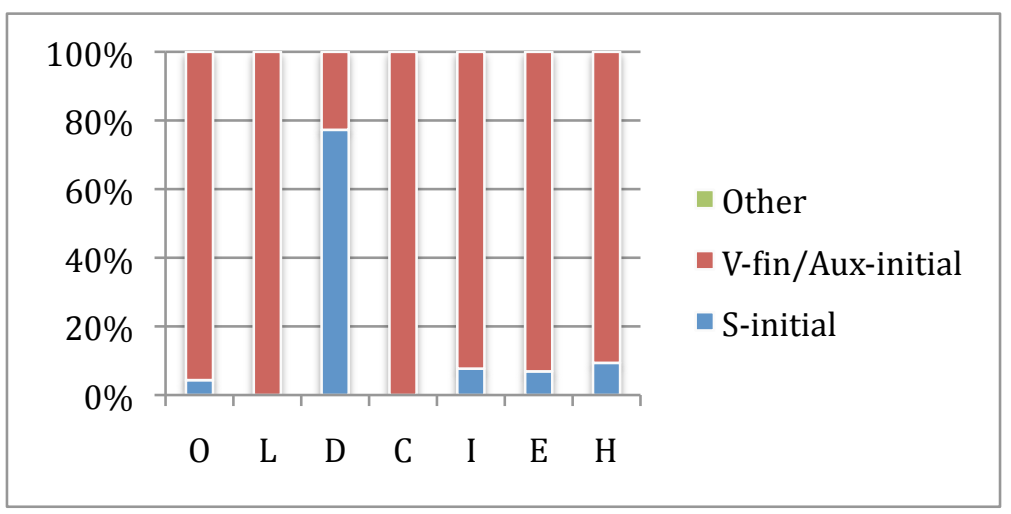

\section{Figure 2: Young Adults' DATA}

The dominant word order pattern for all but one of the young adults is, like the senior adults and the immersion school children, finite verb-initial. D presents something of an anomaly: why is he different? Here again, it appears to be a question of input. Most of the young adults had a substantial amount of schooling in Breton, but D learnt Breton later, at a Centre de Formation or 'Training Centre', and did not speak Breton with family members. 


\section{CONCLUSIONS}

Negative utterances in Breton seem to show clear word order patterns among different groups of Breton speakers, as can be seen from a comparison of three groups:

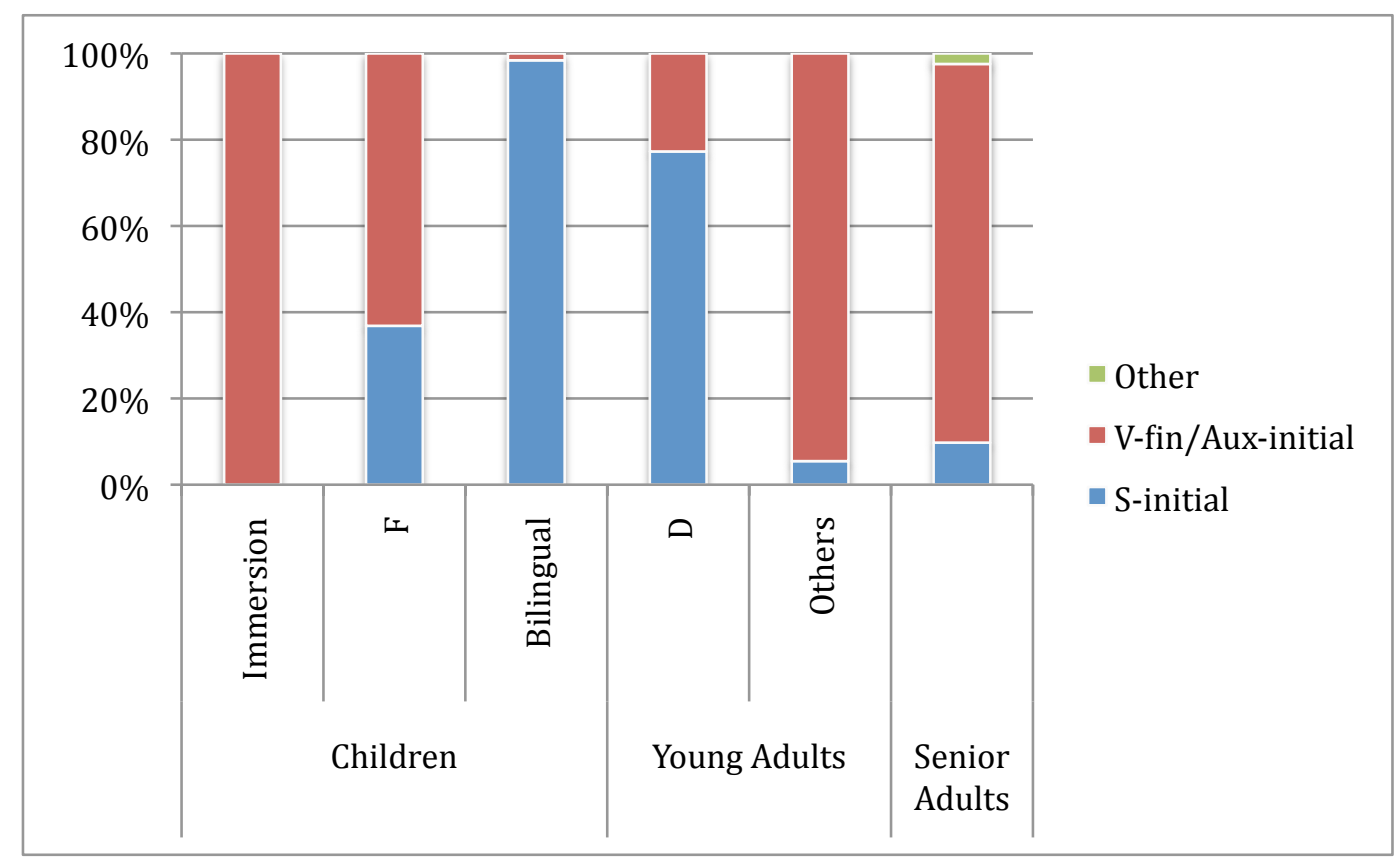

\section{FiguRE 3: COMPARISON}

The amount of input children receive, both at school and at home, affects their use of word order. Data from the young adults suggests that while these effects can be temporary, they may also persist into adulthood, particularly if speakers receive little input outside of schooling or classes. Further research is needed to explore these patterns more fully. Nonprogressive negatives, as well as non-negatives and embedded clauses are a priority for future work.

\section{REFERENCES}

Heine, Bernd and Tania Kuteva. 2005. Language Contact and Grammatical Change (Cambridge: Cambridge University Press)

Hornsby, Michael. 2005. 'Néo breton and questions of authenticity' Estudios de Sociolingüística 6(2): 191-218

Kervella, Frañsez. 1947. Yezhadur bras ar brezhoneg (La Baule: Skridou Breizh)

Press, J. Ian. 1986. A Grammar of Modern Breton (Berlin: Mouton de Gruyter)

Ternes, Elmar. 1992. 'The Breton Language' in Donald MacAulay (ed.) The Celtic Languages (Cambridge: Cambridge University Press) 371-452

Timm, Lenora A. 1989. 'Word order in twentieth-century Breton' Natural Language \& Linguistic Theory 7: 361-378

Varin, Amy. 1979. 'VSO and SVO Order in Breton' Archivum Linguisticum 10 (new series): 83101 